\title{
THE DEMATEL METHOD IN THE ANALYSIS OF THE RESIDENTIAL REAL ESTATE MARKET IN BIALYSTOK
}

\author{
Elżbieta Gołąbeska, PhD \\ Department of Construction and Environmental Engineering \\ Bialystok University of Technology \\ e-mail: e.golabeska@pb.edu.pl
}

\begin{abstract}
${ }^{1}$
The article is of a dual character. On the one hand, it concerns the analysis of the real estate market in terms of investment attractiveness and the influence of particular attributes of property on attractiveness itself. On the other hand, it proposes the use as a research tool selected using one of the multicriteria methods (DEMATEL), which is an alternative to commonly used statistical methods. The theoretical part of the work is completed by a brief computational example which deals with the analysis of factors affecting the prices of residential real estate on a local scale.
\end{abstract}

Key words: real estate market, investment risk, multicriteria methods, DEMATEL method.

JEL Classification: C50.

Citation: Gołąbeska E., 2018, The Dematel Method in the Analysis of the Residential Real Estate Market in Bialystok, Real Estate Management and Valuation, vol. 26, no. 1, pp. 16-25.

DOI: $10.2478 /$ remav-2018-0002

\section{Introduction}

Analysis of the real estate market is an extremely important element in the study of investment process profitability, as well as in the valuation of properties. Statistical methods are undoubtedly an important research tool for enabling various analyses. It should be noted, however, that on the real estate market, it is often necessary to take into account both quantitative data as well as a variety of qualitative data.

This article uses multicriteria methods to evaluate the relations between the features of properties considered to be price decliners. The case study was carried out on the example of the residential real estate market in Bialystok. The DEMATEL method was the most appropriate for this type of analysis.

Therefore, the aim of the work is to examine the strength of relations between different characteristics of real estate. The analysis was focused on land property with residential s (houses) and residential real property (apartments).

The research thesis in this case can be determined as follows: "multicriteria methods are useful in the study of the real estate market and can provide added value to research using classical statistical methods, such as the correlation coefficient and linear regression model."

The real estate market is increasingly perceived as attractive where investment is concerned, and the value of real estate as an investment object is the starting point for decision-making. The importance of this process in not only connected with the behavioral aspects of investors often described in literature (BRZEZICKA, WIŚNIEWSKI 2012) but also with fluctuations in the economy, , which are generally taken into account when making investment decisions (CHRÓsTNA 2014). For an

\footnotetext{
${ }^{1}$ The research was carried out as part of the Work No. S/WBiIŚ/4/16 and financed from the resources for science of the Ministry of Science and Higher Education.
} 
investor, the most important thing is efficiency, which translates directly into profits (GOŁĄBESKA 2011). Investing capital in the real estate market is accompanied by high risk. Therefore, the investor must take into account and consider all the factors that affect the profitability of investments (GOŁĄBESKA 2015). This theme is taken by many authors in different types of publications. The real estate market, from this point of view, has been elaborated on for many years by Ewa KucharskaStasiak, locating it in the widely understood market economy (KUCHARSKA-STASIAK 2000; KUCHARSKASTASIAK 2006). The essence of these considerations is primarily the value of the property and its relationship to the prices on a given market (MĄCZYŃSKA, PRYSTUPA, RYGIEL 2009). The analyses are carried out are not so much as an indication of the factors affecting the profitability of real estate investments, but the level of their mutual relations which may influence that profitability (UNSAL 2016; GAWRON, STRACCZKOWSKI 2015). In this regard, statistical and econometric methods are primarily used. Given the fact that the conducted analyses are said to be useful in making investment decisions, sophisticated multi-criteria methods are used more and more often for this purpose (EUNIEWSKA, TARCZYŃSKI 2006). Such issues, in relation to the capital market in Poland, are dealt with by, among others, Trzaskalik, Dytczak and Łuniewska (TRZASKALIK 2014; DYTCZAK 2010; ŁUNIEWSKA, TARCZYŃSKI 2006).

Therefore, it seems reasonable to analyze the usefulness of methods of multi-criteria decisionmaking (support) as research tools on the real estate market. This elaboration presents the increasing popularity of the DEMATEL (Decision Making Trial and Evaluation Laboratory) method. Due to the fact that this method is not common in the relevant market, there is reason to start off by providing some basic information about it. Afterwards, a calculation algorithm evaluating the usefulness of the DEMATEL method for a select issue connected with the analysis of the residential real estate market analysis issues was presented on a chosen theoretical example.

The considerations are theoretical, with case analysis carried out.

\section{DEMATEL method - General Information}

The DEMATEL method was developed in Switzerland in the seventies of the twentieth century. The idea of the creators (GABUS, FONTEL 1973) was for it to serve as a tool that would make it possible to solve complex problems and analyze a variety of causal links. The DEMATEL method is being used increasingly to solve various social, economic, or technical problems. In this article, the DEMATEL method is used to sample issues of real estate market analysis, namely to identify potential relationships between the features of a property which are important from the point of view of valuation.

The residential real estate market is inherently a local market. This could mean that the impact of local factors influencing supply and demand is large enough to disrupt the impact of macroeconomic factors. One of the pivotal determinants of the general phenomena and processes on the real estate market are the prices of properties. Typically, correlation analysis and linear regression are used in this type of research to analyze the relationships between features of real estate and property prices.

In these deliberations attention will be focused on the mutual relations between the explanatory variables that have an impact on property prices.

\section{DEMATEL method in research on the relationships between the characteristics of properties}

Independent variables affecting the prices of apartments and houses are in specific relationships with each other, which can be demonstrated by using the commonly applied correlation methods, which, in the assessment of experts, lead to reliable results. However, in order to prove that this is not the only tool for studying the dependence of variables, the present article attempts to use one of the multicriteria methods, which are classified as soft modeling tools, as it is sometimes necessary to use such methods to demonstrate extensive expertise and sensitivity, for example in assessing the impact of buildings on each other.

The DEMATEL method was developed to solve problems of a complex nature, global or regional in character. It was created in the 70s of the twentieth century by E. Fontel and A. Gabus in connection with the need to solve complex problems of identifying causal links.

A crucial assumption of this method is the comparison of objects in pairs. These objects are usually the considered factors, variants of a decision or event. When making comparisons, the interaction between the objects being compared should be kept in mind. After considering the set of relations that 
exist between the compared objects, it is possible to build a graph of direct impact that illustrates these relations and is easy to interpret. The peaks of the graph represent the analyzed objects, while the lines connecting the pairs of peaks express the strength and direction of the causal link (DYTCZAK, 2011).

The strength of the relation of the impact of once object on another within a pair is evaluated using an ordinal, discrete scale consisting of $0-\mathrm{N}$ levels. The creators of the method adopted scale values of $\mathrm{N}=4$, where different levels have the following meaning:

- 0 - no impact,

- 1 - little impact,

- 2 - medium impact,

- 3 - large impact

- 4 - very large impact.

Currently, there are also other scales e.g. $\mathrm{N}=3, \mathrm{~N}=5$ and $\mathrm{N}=8$. The scale variant choice is determined by practical reasons (DYTCZAK 2010).

In order to preserve readability of the direct impact graph, lines reflecting the lack of relationships are omitted, thus expressed by an assessment level of zero (DYTCZAK 2010).

Based on the graph, it is possible to directly influence the establishment of a direct relationship matrix (A), which is a square matrix, the size of which is equal to the number of analyzed objects. Its individual lines correspond to objects found in the comparisons as the first, and the columns correspond to objects occurring in comparisons as the second. Due to the fact that the DEMATEL method does not allow for taking into account the impact of the object on itself, the elements on the main diagonal of the matrix are equal to zero (KOBRYŃ 2014).

The next step is to determine the overall impact of the matrix $(\mathrm{T})$. This is carried out by firstly normalizing the matrix of direct influence (A). The result is the normalization matrix $(\mathrm{X})$. This was originally done by dividing each of its elements by the maximum value of the sum of the row.

$$
X=\frac{A}{\max _{i}\left\{\sum_{j=1}^{n} a_{i j}\right\}}
$$

Currently, the standardization matrix (A) uses a maximum amount of elements located in columns.

$$
X=\frac{A}{\max _{j}\left\{\sum_{i=1}^{n} a_{i j}\right\}}
$$

In order to achieve the matrix of total impact $(T)$, each successive power of the matrix $(X)$ should be added to each other according to the following formula:

$$
T=X(I-X)^{-1}
$$

where (I) is a unitary matrix of size corresponding to the number of objects considered (DYTCZAK 2011).

With the matrix $(\mathrm{T})$, it is possible to determine the values of indicators describing the relationships which exist between the analyzed objects. These indicators are called items $\left(\mathrm{s}^{+}\right)$and the relationship (s-). Their values are obtained by the sum or difference of the sums of rows and columns of the matrix (T). With regard to the $\mathrm{i}$-th object, this operation is described by the formula (DYTCZAK 2011):

$$
\begin{aligned}
& s_{i}^{+}=R_{i}+C_{i}, \\
& s_{i}^{-}=R_{i}-C_{i},
\end{aligned}
$$

where: $\mathrm{Ri}$ - the sum of the line, $\mathrm{C} \mathrm{i}$ - value of the column sum.

The indicator shows the importance of the role of the object in the process of determining the structure of relations between objects, whereas the ratio describes the general nature.

Its positive value indicates a causal nature of the property, while a negative value indicates the nature and effect. The role and the degree of the influence of individual objects are proportional to the values of these indicators. For graphic illustration of the characteristics of objects, values of significance indicators and relations can be presented in the coordinate system: position - relation (KOBRYŃ 2014).

The values of meaning and relations can be used to determine the weight values. KOBRYŃ (2014) proposes to determine a weight value proportional to the average value of the respective pair of $\left(\mathrm{s}^{+}\right)$ and (s-) indices. The average values are obtained as follows:

$$
s_{1}^{s} r=\frac{1}{2}\left(s_{1}^{+}+s_{1}^{-}\right)=\sum_{j=1}^{n} s_{i, j}
$$


This method is only possible to use when the average values of $\left(\mathrm{s}^{+}\right)$and (S-) are positive. To establish the standard weight value, the following formula is used:

$$
w_{j}=\frac{s_{j}^{s r}}{\sum_{j=1}^{n} s_{j}^{s r}}
$$

DYTCZAK (2010) describes a wide variety of areas in which the DEMATEL method is currently being applied. This confirms its universality and multidisciplinary capabilities. Recently, there has also been an attempt to apply this method for the analysis of the characteristics of the real estate market (OGRODNIK 2014).

4. DEMATEL method in the multicriteria analysis between features of houses in Bialystok (land properties built up with residential buildings)

At the beginning of the research carried out with the application of the DEMATEL method, the analyzed issue should be defined and its components determined. The research in this article is based on common features of land property with residential building and residential real property.

The following analysis was carried out on the characteristics of properties, which are usually understood as the attributes that affect their value. In the case of landed property built-up with a residential building, these are:

- Usable floor area (C1)

- Land area (C2)

- Building age (C3)

- Standard of finish (C4)

- Type of building area (C5).

After defining the characteristics of the market which will be investigated, the strength and direction of the links between them were determined. Evaluation was carried out in pairs, according to the previously described scale ( 0 to 4$)$. Table 1 presents the ratings assigned to individual pairs of features and next constructing the matric of direct relations $\mathrm{A}$.

Table 1

Evaluation of the direct relations between the characteristics of the market

\begin{tabular}{|c|c|c|c|c|c|c|}
\hline $\begin{array}{l}\text { Market features of land property built-up with a } \\
\text { residential building }\end{array}$ & 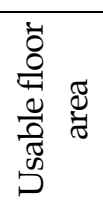 & 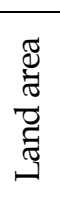 & 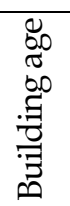 & 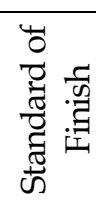 & 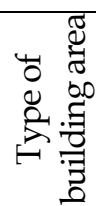 & $\sum_{\text {S }}$ \\
\hline Usable floor area (C1) & 0 & 0 & 0 & 1 & 0 & 1 \\
\hline Land area (C2) & 3 & 0 & 0 & 0 & 4 & 7 \\
\hline Building age (C3) & 3 & 0 & 0 & 3 & 3 & 9 \\
\hline Standard of finish (C4) & 0 & 0 & 0 & 0 & 0 & 0 \\
\hline Type of building area (C5) & 3 & 0 & 0 & 1 & 0 & 4 \\
\hline SUM & 9 & 0 & 0 & 5 & 7 & \\
\hline
\end{tabular}

Source: Own study.

$$
\mathbf{A}=\left[\begin{array}{lllll}
0 & 0 & 0 & 1 & 0 \\
3 & 0 & 0 & 0 & 4 \\
3 & 0 & 0 & 3 & 3 \\
0 & 0 & 0 & 0 & 0 \\
3 & 0 & 0 & 1 & 0
\end{array}\right]
$$

Mutual relations existing between the objects and their strength can also be presented in the form of a direct effect graph (Figure 1). 


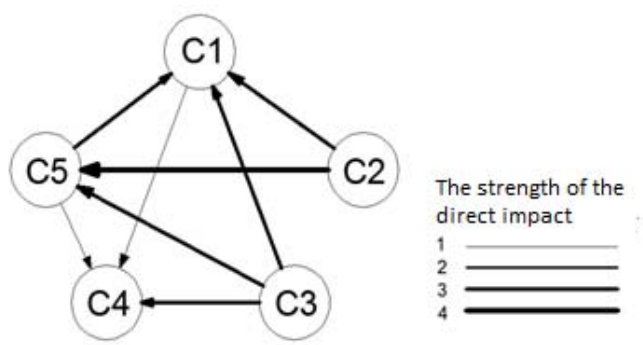

Fig. 1. Graph showing the direct relationship between the characteristics of the market. Source: own study.

The result of the normalization of the matrix of direct relations $A$ is the $X$ matrix. The row and column sums indicated in Table 4.3 did not exceed 9. Thus, normalization was performed by dividing matrix A by 9 .

$$
\begin{gathered}
\mathbf{X}=\left[\begin{array}{lllll}
0 / 9 & 0 / 9 & 0 / 9 & 1 / 9 & 0 / 9 \\
3 / 9 & 0 / 9 & 0 / 9 & 0 / 9 & 4 / 9 \\
3 / 9 & 0 / 9 & 0 / 9 & 3 / 9 & 3 / 9 \\
0 / 9 & 0 / 9 & 0 / 9 & 0 / 9 & 0 / 9 \\
3 / 9 & 0 / 9 & 0 / 9 & 1 / 9 & 0 / 9
\end{array}\right] \\
\mathbf{X}=\left[\begin{array}{llllll}
0.0000 & 0.0000 & 0.0000 & 0.1111 & 0.0000 \\
0.3333 & 0.0000 & 0.0000 & 0.0000 & 0.4444 \\
0.3333 & 0.0000 & 0.0000 & 0.3333 & 0.3333 \\
0.0000 & 0.0000 & 0.0000 & 0.0000 & 0.0000 \\
0.3333 & 0.0000 & 0.0000 & 0.1111 & 0.0000
\end{array}\right]
\end{gathered}
$$

The matrix of the overall impact of $\mathrm{T}$ has been determined in accordance with the algorithm described above. Subsequent operations were performed in Microsoft Excel. The final form of Matrix $\mathrm{T}$ is presented below.

$$
\mathbf{T}=\left[\begin{array}{lllll}
0.0000 & 0.0000 & 0.0000 & 0.1111 & 0.0000 \\
0.4815 & 0.0000 & 0.0000 & 0.1029 & 0.4444 \\
0.4444 & 0.0000 & 0.0000 & 0.4198 & 0.3333 \\
0.0000 & 0.0000 & 0.0000 & 0.0000 & 0.0000 \\
0.3333 & 0.0000 & 0.0000 & 0.1481 & 0.0000
\end{array}\right]
$$

Based on the $\mathrm{T}$ matrix of overall impact, the values of indicators of significance and relationships and the weights of individual features were designated. The results of calculations and ratios are presented in Table 2.

\begin{tabular}{|c|c|c|c|c|c|c|c|}
\hline \multirow[t]{2}{*}{ No. } & \multirow[t]{2}{*}{ Market feature } & $\begin{array}{l}\text { Sum } \\
\text { successive } \\
\text { rows of } T \\
\text { matrix }\end{array}$ & $\begin{array}{l}\text { Sum of each } \\
\text { column of } \\
\text { the } T \text { matrix }\end{array}$ & $\begin{array}{l}\text { Significance } \\
\text { indicator }\end{array}$ & $\begin{array}{l}\text { Rela- } \\
\text { tionship } \\
\text { ind. }\end{array}$ & $\begin{array}{l}\text { Average } \\
\text { rates }\end{array}$ & Scales \\
\hline & & $\boldsymbol{R}_{i}$ & $C_{i}$ & $s^{+}$ & $s^{-}$ & $S^{a v}$ & \\
\hline $\mathrm{C} 1$ & Usable floor area & 0.1111 & 1.2593 & 1.3704 & -1.1481 & 0.1111 & 0.04 \\
\hline $\mathrm{C} 2$ & Land area & 1.0288 & 0.0000 & 1.0288 & 1.0288 & 1.0288 & 0.36 \\
\hline $\mathrm{C} 3$ & Building age & 1.1975 & 0.0000 & 1.1975 & 1.1975 & 1.1975 & 0.42 \\
\hline $\mathrm{C} 4$ & Standard of finish & 0.0000 & 0.7819 & 0.7819 & -0.7819 & 0.0000 & 0.00 \\
\hline \multirow[t]{2}{*}{ C5 } & Type of building area & 0.4815 & 0.7778 & 1.2593 & -0.2963 & 0.4815 & 0.17 \\
\hline & & & & & & $\sum=2.8189$ & 1.00 \\
\hline
\end{tabular}

Table 2

Indicators of significance and relationships, and the weights of individual market features

Source: Own study.

The values of significance and relations assigned to the individual features of real estate built-up with residential buildings are shown in the form of a graph (Figure 2). 
The values of the significance indicator were marked on the horizontal axis, while the values of the relationship indicator were marked on the vertical axis. The sign of the relationship indicator indicates the role that the element plays in the system. A positive value indicates that it is a causal element, whilst a negative one - that it has a resultant character. The absolute value of this indicator determines how significant this role is (MICHNIK 2013).

Analyzing the results obtained from the carried out calculations, it can be concluded that the usable floor area of the house plays a prominent role in shaping the causal effect or nature of the individual objects, as evidenced by the high rates of the significance indicator.

The highest positive ratio of the relationship indicator was obtained by factor $\mathrm{C} 3$ - the year of construction. It has the nature of a causal relation to all other objects. This means that the feature has the greatest effect on other elements. The area of the plot (C2) can be also specified as a cause, but it has an impact on all of the objects besides $\mathrm{C} 3$, which has a higher value of the relationship indicator. Features with negative values of relationship indicator have a causal effect. These are: usable floor area (C1), the standard of finish (C4), and the type of building area (C5). This means that the state of these factors is, to a large degree, the effect of the impact of market features with of a causal nature.

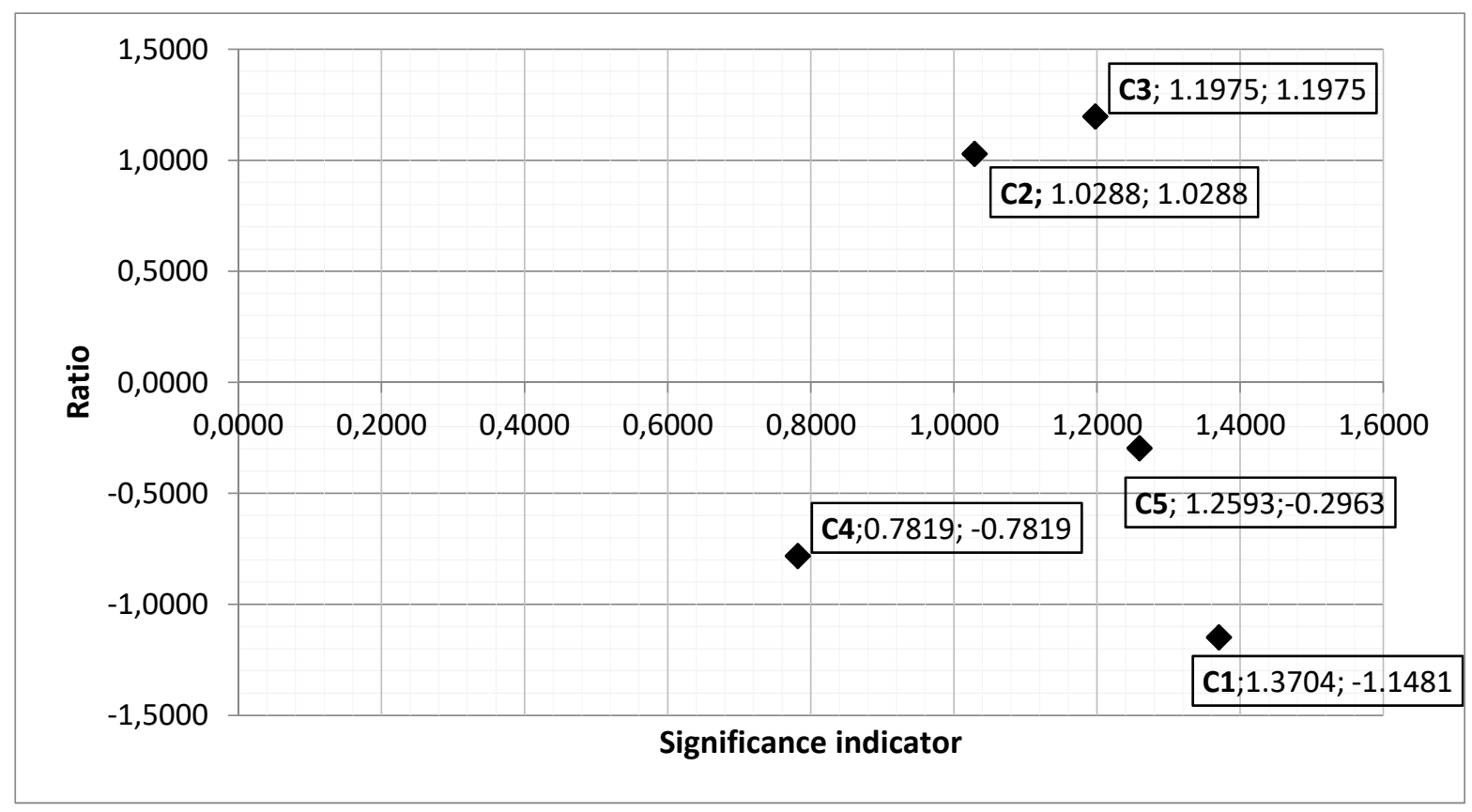

Fig. 2. Matter - relations map. Source: own study.

Summarizing the analysis, among the analyzed features of houses, a pivotal role was played by the age of the building (year of construction), which has the strongest effects on other features. The importance of this attribute was set at 0.42 . The attribute which is under the greatest influence of other features is the usable floor area of the house (weight 0.04).

5. DEMATEL method in multicriteria analysis of relationships between the features of flats in Bialystok (residential real property)

In the case of studying the relationships between the features of residential real properties the procedure algorithm is analogous to that described above. The following features of flats were analyzed:

- Usable floor area (C1)

- Building age (C2),

- The position on the floor (C3)

- Standard of finish (C4). 
Table 3

Evaluation of the direct relationships between the market features

\begin{tabular}{|c|c|c|c|c|c|}
\hline Market features of residential real properties & 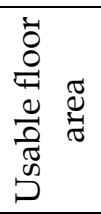 & 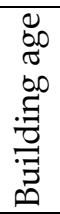 & 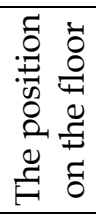 & 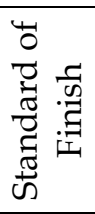 & $\sum_{\infty}$ \\
\hline Usable floor area (C1) & 0 & 0 & 0 & 1 & 1 \\
\hline Building age (C2) & 2 & 0 & 0 & 3 & 5 \\
\hline The position on the floor (C3) & 2 & 0 & 0 & 1 & 3 \\
\hline Standard of finish (C4) & 0 & 0 & 0 & 0 & 0 \\
\hline SUM & 4 & 0 & 0 & 4 & \\
\hline
\end{tabular}

Source: Own study.

$$
\mathbf{A}=\left[\begin{array}{llll}
0 & 0 & 0 & 1 \\
2 & 0 & 0 & 3 \\
2 & 0 & 0 & 1 \\
0 & 0 & 0 & 0
\end{array}\right]
$$

A graph showing the interrelations between the considered elements and their strength is presented in Figure 3.
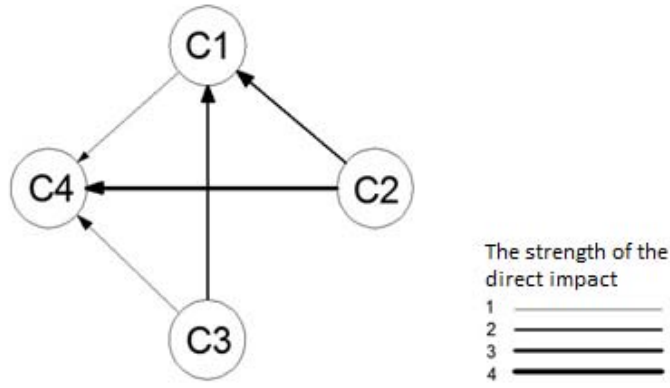

Fig. 3. Graph showing the direct relations between the market features. Source: Own study.

The normalization of Matrix A of direct relations was carried out by dividing it by the maximum sum of rows, which amounted to 5 . The result of the normalization is Matrix X.

$$
\begin{gathered}
\mathbf{X}=\left[\begin{array}{llll}
0 / 5 & 0 / 5 & 0 / 5 & 1 / 5 \\
2 / 5 & 0 / 5 & 0 / 5 & 3 / 5 \\
2 / 5 & 0 / 5 & 0 / 5 & 1 / 5 \\
0 / 5 & 0 / 5 & 0 / 5 & 0 / 5
\end{array}\right] \\
\mathbf{X}=\left[\begin{array}{llll}
00000 & 0.0000 & 0.0000 & 0.2000 \\
0.4000 & 0.0000 & 0.0000 & 0.6000 \\
0.4000 & 0.0000 & 0.0000 & 0.2000 \\
0.0000 & 0.0000 & 0.0000 & 0.0000
\end{array}\right]
\end{gathered}
$$

Found below is the final Matrix $\mathrm{T}$ of the overall impact following a series of operations in a spreadsheet.

$$
\mathbf{T}=\left[\begin{array}{llll}
0.0000 & 0.0000 & 0.0000 & 0.2000 \\
0.4000 & 0.0000 & 0.0000 & 0.6800 \\
0.4000 & 0.0000 & 0.0000 & 0.2800 \\
0.0000 & 0.0000 & 0.0000 & 0.0000
\end{array}\right]
$$


Table 4 presents the values of significance and relationship indicators for specific features of the properties and their weights.

Table 4

Significance and relationship indicators of market features

\begin{tabular}{lccccccc}
\hline No. & Market feature & $\begin{array}{c}\text { Sum successive } \\
\text { rows of T } \\
\text { matrix }\end{array}$ & $\begin{array}{c}\text { Sum of each } \\
\text { column of the } \\
\text { T matrix }\end{array}$ & $\begin{array}{c}\text { Significance } \\
\text { indicator }\end{array}$ & $\begin{array}{c}\text { Relation- } \\
\text { ship } \\
\text { indicator }\end{array}$ & $\begin{array}{c}\text { Average } \\
\text { rates }\end{array}$ & Scales \\
\cline { 3 - 8 } & $\boldsymbol{R}_{\boldsymbol{i}}$ & $\boldsymbol{C}_{\boldsymbol{i}}$ & $\boldsymbol{s}^{+}$ & $\boldsymbol{s}^{-}$ & $\boldsymbol{s}^{a v}$ & \\
\hline $\mathrm{C} 1$ & Usable floor area & 0.2000 & 0.8000 & 1.0000 & -0.6000 & 0.2000 & 0.10 \\
\hline $\mathrm{C} 2$ & Building age & 1.0800 & 0.0000 & 1.0800 & 1.0800 & 1.0800 & 0.55 \\
\hline C3 & $\begin{array}{c}\text { The position on } \\
\text { the floor }\end{array}$ & 0.6800 & 0.0000 & 0.6800 & 0.6800 & 0.6800 & 0.35 \\
\hline C4 & Standard of finish & 0.0000 & 1.1600 & 1.1600 & -1.1600 & 0.0000 & 0.00 \\
\hline & & & & & $\sum=1.9600$ & $\mathbf{1 . 0 0}$ \\
\hline
\end{tabular}

Source: Own study.

Figure 4 shows a map of the significance - relationships of features of flats

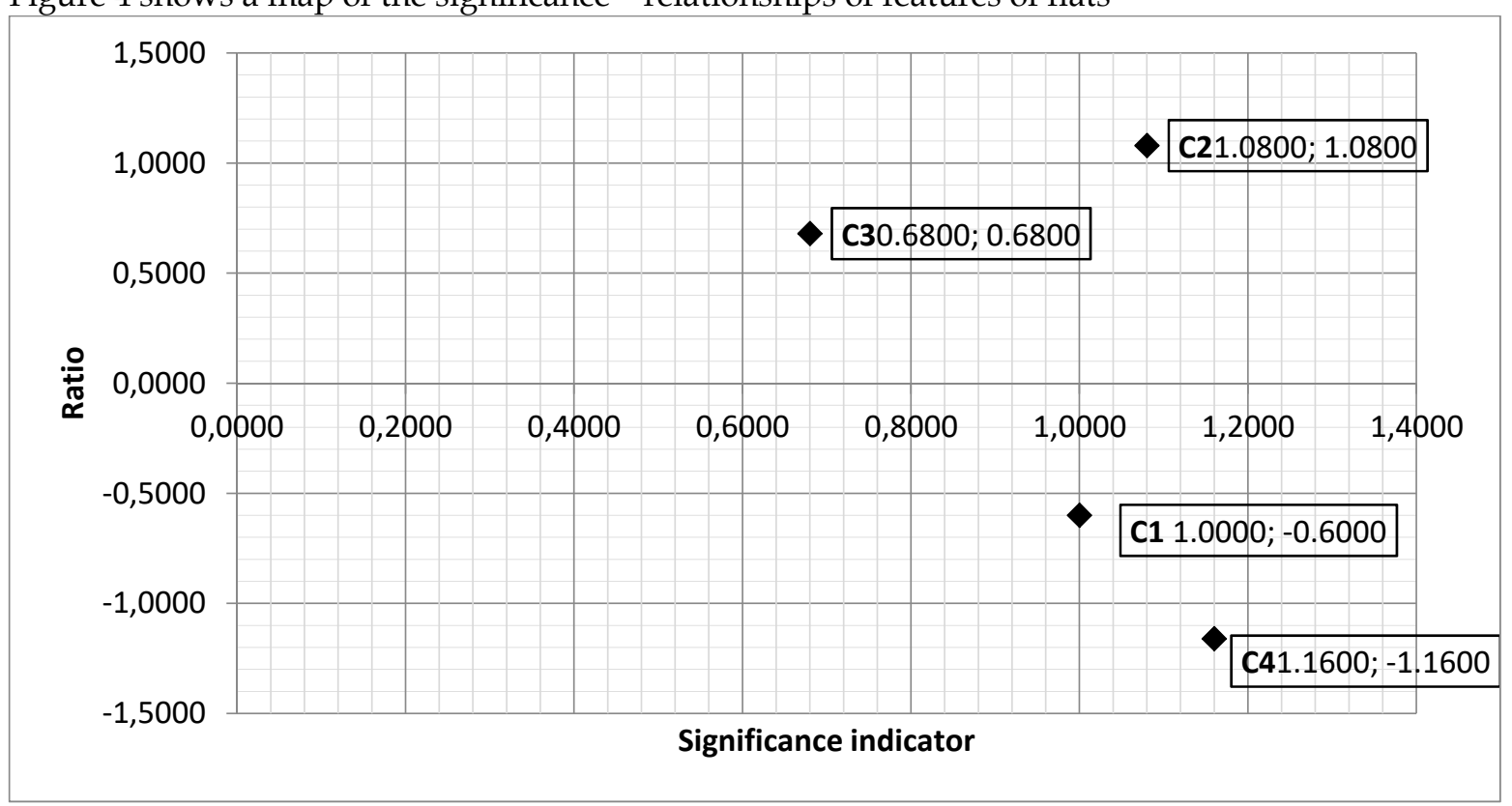

Fig. 4. Significance - relationships map. Source: Own study.

The obtained results lead to certain conclusions. The highest value of the significance indicator was found for the standard of finish (C4), which confirms its dominant role in shaping the relations between the objects under consideration. The age of the building was also characterized by a high value $(\mathrm{C} 2)$.

Analyzing the values of the relationships, the leading role of the C2 characteristic (age of the building) can be observed, which obtained the highest positive value of the indicator. It has a causal character relative to all other aspects of housing properties. Features C1 (usable floor area) and C4 (standard of finish) have negative values and are characterized by a causal character in relation to other factors.

Summing up the conducted research, it can be concluded that the age of the building holds a pivotal role and exerts the strongest influence on other characteristics. This feature also obtained the highest value of significance, i.e. 0.55. The factor that was found to be least dependent on the other analyzed characteristics is the standard of finish, with its weight equal to 0.00 . 


\section{Conclusions}

The real estate market is very complex, and its dynamics and size are influenced by three overlapping main factors, i.e. supply, demand and price. Among these factors, the main determinant of real estate market development is price, implying the price that is an incentive for investors to take specific decisions.

The price of real estate is very closely related with its value. Value, and thus price, depend on many factors that are interconnected. The present article focuses on one of the available multicriteria methods which can identify potential relations between the features of a housing property which are important when value is concerned. In order to determine which factors influence most influence each other, which may translate into significance in the development of housing real estate prices in Bialystok, a group of factors for each type of real estate in question had to be selected. For this purpose, we analyzed a set of sales offers posted on two Internet portals, i.e.: "www.otodom.pl" and "www.olx.pl". It was decided that in the case of land built up with residential buildings, the following features will be included: usable floor area of the house, land area, building age, standard of finish and type of building. In the case of flats, the impact of the following features was subjected to analyses: the usable floor area of the flat, the age of the building, location in regards to the floor, and the standard of finish of the residential real property.

Independent variables affecting the prices of houses and flats area in specific relationships with each other. This can be demonstrated by conventional statistical methods typically used in this type of analysis. Research using correlation and regression is able to assess the relationships between features without specifying the direction of impact. To investigate the exact relationship between the features of a property and the strength of their influence, the DEMATEL method was used. The analysis carried out by this method allowed for the emergence of features that play the biggest role in shaping the character of the individual objects. Indicators derived from calculations provide information about the objects and make it possible to determine either their causal or effect character.

Such analyses may prove useful in making investment decisions on the real estate market. The simple model of the DEMATEL method allows for evaluating the relationship of the direct influence of individual attributes. Mathematical transformations use a matrix of direct influence A which expresses this relationship, and, on its basis, the matrix of the total (both direct and indirect) influence $\mathrm{T}$ is derived. The elements of this matrix allow for determining the values of two characteristic indicators: position (positivity) and relationships, identifying the character of the analyzed factors, both in the context of their role in the process of establishing the structure of the influence of factors as well as the their influence on the remaining ones. As a result, the degree of the total impact of the factors can be easily determined, and they can, consequently, be ranked and identified (as having a causal and effect character). The results of the analysis of the total impact can also be visualized using the so-called overall impact map showing the relationships of the influence occurring between the individual factors (DYTCZAK, 2010).

The qualitative nature of the results obtained by DEMATEL may provoke the use of more specialized methods that are better adapted for broader analyses. Improvements to this method are offered by TSENG (2009), who proposes changes in the calculation procedure and presents its results. The variant of the method that he refers to as EDEMATEL enables the conjugation of two points of view while analyzing the issue under consideration. This goal was achieved by including, in the single matrix $X^{*}$, information on the direct impact of the system elements resulting from two independent points of view on considered issue. The original proposal (WU at el. 2011) uses a double analysis, conducted in the context of the risks and benefits that undoubtedly accompany investments in the real estate market.

In conclusion, we can state that the analyses provide a general view on the mutual relations between the determinants of property prices in the analyzed period in the given area.

The research was carried out as part of Work No. S/WBiIŚ/4/16 and financed from the resources for science of the Ministry of Science and Higher Education.

\section{References}

BRZEZICKA J., WiśNIEWSKI R., 2012, Behavioral Aspects of the Real Estate Market, TNN Studies and Materials, Vol. 20, No. 2, Olsztyn, Poland. 
CHRÓstNA R., 2014, Fluctuations of Economic Activity in the Housing Market, Newsletter of the Association of Valuers of the Wielkopolska No. 1-2, pp. 39-40.

DYTCZAK M., 2010, Wybrane metody rozwiązywania wielokryterialnych problemów decyzyjnych $w$ budownictwie (Selected Methods of Solving Multicriteria Decision-Making Problems in the Construction Industry), Wydawnictwo Politechniki Opolskiej (Opole University of Technology Publisher).

Gabus A., Fontela E.: Perceptions of the World Problematic: Communication Procedure, Communicating with those Bearing Collective Responsibility, DEMATEL 1. Battelle Geneva Research Centre, Geneva 1973.

GAWRON H., STRĄCZKOWSKI Ł., 2015, Premises Consideration of Qualitative Factors in the Study of the Housing Market, Newsletter of the Association of Valuers of the Wielkopolska Region, No. 1, (43).

GOŁĄBESKA E., 2011, Efektywność inwestowania na rynku nieruchomości przy uwzględnieniu ryzyka (The Effectiveness of Investing in the Real Estate Market Taking into Account the Risks), Scientific Papers "Studies and Works Management and Finance College" School of Economics in Warsaw, Scientific Papers 110.

GOŁĄBESKA E., 2015, Identyfikacja wybranych czynników wptywajacych na opłacalność inwestowania na rynku nieruchomości (Identification of Selected Factors Affecting the Profitability of Investing in Real Estate), Newsletter of the Association of Valuers of the Wielkopolska Region "The problems of Real Estate Market", No. 2/2015 (44), pp. 77-84.

KOBRYŃ A., 2014, Wielokryterialne wspomaganie decyzji w gospodarowaniu przestrzenią (Multicriteria Decision Support in Spatial Management), Wydawnictwo Difin (Difin Publisher), Warsaw, Poland.

KUCHARSKA-STASIAK E., 2000, Nieruchomość a rynek (Property vs Market), Wydawnictwo naukowe PWN (Polish Scientific Publishers).

KUCHARSKA-STASIAK E., 2006, Nieruchomość w gospodarce rynkowej (Real Estate in the Market Economy), PWN (Polish Scientific Publishers), Warsaw, Poland.

ŁUNIEWSKA M., TARCZYŃSKI W., 2006, Metody wielowymiarowej analizy porównawczej na rynku kapitałowym (Methods of Multidimensional Comparative Analysis on Capital Market), Wydawnictwo Naukowe PWN ((Polish Scientific Publishers), Warsaw, Poland.

MĄCZYŃSKA E., PRYSTUPA M., RYGIEL K., 2009, Ile jest warta nieruchomość (How Much is the Real Property Worth), Poltext, Warsaw, Poland.

MiCHNIK J., 2013, Wielokryterialne metody wspomagania decyzji w procesie innowacji (Multicriteria Methods of Decision Support in the Process of Innovation), Wydawnictwo Uniwersytetu Ekonomicznego w Katowicach (Publishing House of the University of Economics in Katowice), Katowice, Poland.

OGRODNIK K., 2014, Analiza cech rynkowych nieruchomości przy użyciu metody DEMATEL (Analysis of the Characteristics of the Real Estate Market Using the DEMATEL Method), Wydawnictwo Bauhaus (Bauhaus Publisher), Białystok, Poland.

PACUK P., 2015, Czynniki decydujące o cenach nieruchomości na terenie Biategostoku (Factors Determining Real Estate Prices in Bialystok), praca inżynierska (engineer's thesis).

SAAty T.L., 1980, The Analytic Hierarchy Process: Planning, Priority Setting, Resource Allocation, McGrawHill, New York.

TSENG M.-L. 2009, Using the Extension of DEMATEL to Integrate Hotel Service Quality Perceptions into a Cause-Effect Model in Uncertainty, Expert Systems with Applications, Vol. 36(5), pp. 9015-9023.

TRZASKALIK T, 2014, Wielokryterialne metody wspomagania decyzji (Multi-criteria decision support), PWE, Warszawa

UnSAL O., 2016, Property Price Separation Between Land and Building Components, Journal of Real Estate Research, Vol. 38, No. 2, pp. 205-228. 